\title{
SKIPPERS AND BUTTERFLIES OF THE POLICE COULEE AREA, ALBERTA
}

HAROLD W. PINEL, 1017 - 19 Avenue N.W., Calgary, Alberta T2M 0Z8 and NORBERT G. KONDLA, Resource Evaluation and Planning Division, Alberta Energy and Natural Resources, 530 - 8 Street S., Lethbridge, Alberta. T1J 2J8

The study area of $36 \mathrm{mi}^{2}$ is Township 1, Range 13, west of the Fourth Meridian. The Alberta - Montana boundary forms the southern border of the study area. The northern end of the study area is bordered by special features such as the Milk River, Writing-on-Stone Provincial Park and Van Cleeve Coulee. Bisecting the study area is the north-south running Police Creek and its spectacular associated coulee system. Rising from the plains are the scenic Sweetgrass Hills of Montana, immediately south of the study area. Elevation ranges from 3140 to $4000 \mathrm{ft}$.

Two ecoregions make up the study area. The northern two-thirds of the land is classified as being in the Short Grass Ecoregion, and the southern third as in the Mixed Grass Ecoregion. ${ }^{9}$ This boundary is based primarily on the soil boundary separating the Brown and Dark Brown Chernozems. Visually, the boundary is noticeable by the higher elevation and more luxuriant grass vegetation of the Mixed Grass Ecoregion. The area has a continental prairie climate characterised by cold winters, warm summers, and low precipitation. The mean annual precipitation is $21 \mathrm{~cm}$ and sometimes as low as 17 $\mathrm{cm}$ in the Short Grass region, while the Mixed Grass Ecoregion has a mean of $26 \mathrm{~cm}$ and a low of $20 \mathrm{~cm}$. The increased precipitation is due to the increased elevation which increases upslope precipitation during an easterly flow.

A diverse landscape and an associated variety of microenvironments are largely responsible for the heterogeneity of the vegetation. The degree and stability of slope, exposure to wind and sun, availabili- ty of moisture, and soil type are key factors influencing plant growth on a given site. The change from one plant community to another can be abrupt and well defined, or it may be gradual and intergrading. Figures 1 to 3 illustrate the topography and habitats of the study area.

For discussing the butterflies, it is convenient to group the habitats into four major catergories: grasslands, bare and eroding slopes, shrub communities and riverine forest.

The majority of the study area is featured by an undulating upland plain, which becomes more rolling to the south as it merges into the lower slopes of the Sweetgrass Hills. Much of the upland plain has been disturbed by cultivation and cattle grazing. Mixed grassland occurs on the upland plain, on older portions of the floodplain, and on relatively stable coulee and valley slopes. Spear grasses (Stipa spp.), Blue Grama Grass (Bouteloua gracilis), June Grass (Koeleria cristata) and wheat grasses (Agropyron spp.) are the dominant grasses. In the more xeric sites, Blue Grama Grass and Spear Grass (Stipa comata) are predominant. In mesic areas, other species of spear grasses and wheat grasses dominate.

On dry exposed coulee edges, slopes and sandstone ledges, the following species are common: Creeping Juniper Uuniperus horizontalis), Moss Phlox (Phlox hoodii), Musineon (Musineon divaricatum), Cryptanthe (Cryptantha nubigena), Smooth Blue Beard-tongue (Penstemon nitidus), Butte Marigold (Hymenoxys acaulis), Chamaerhodos (Chamaerhodos erecta), 


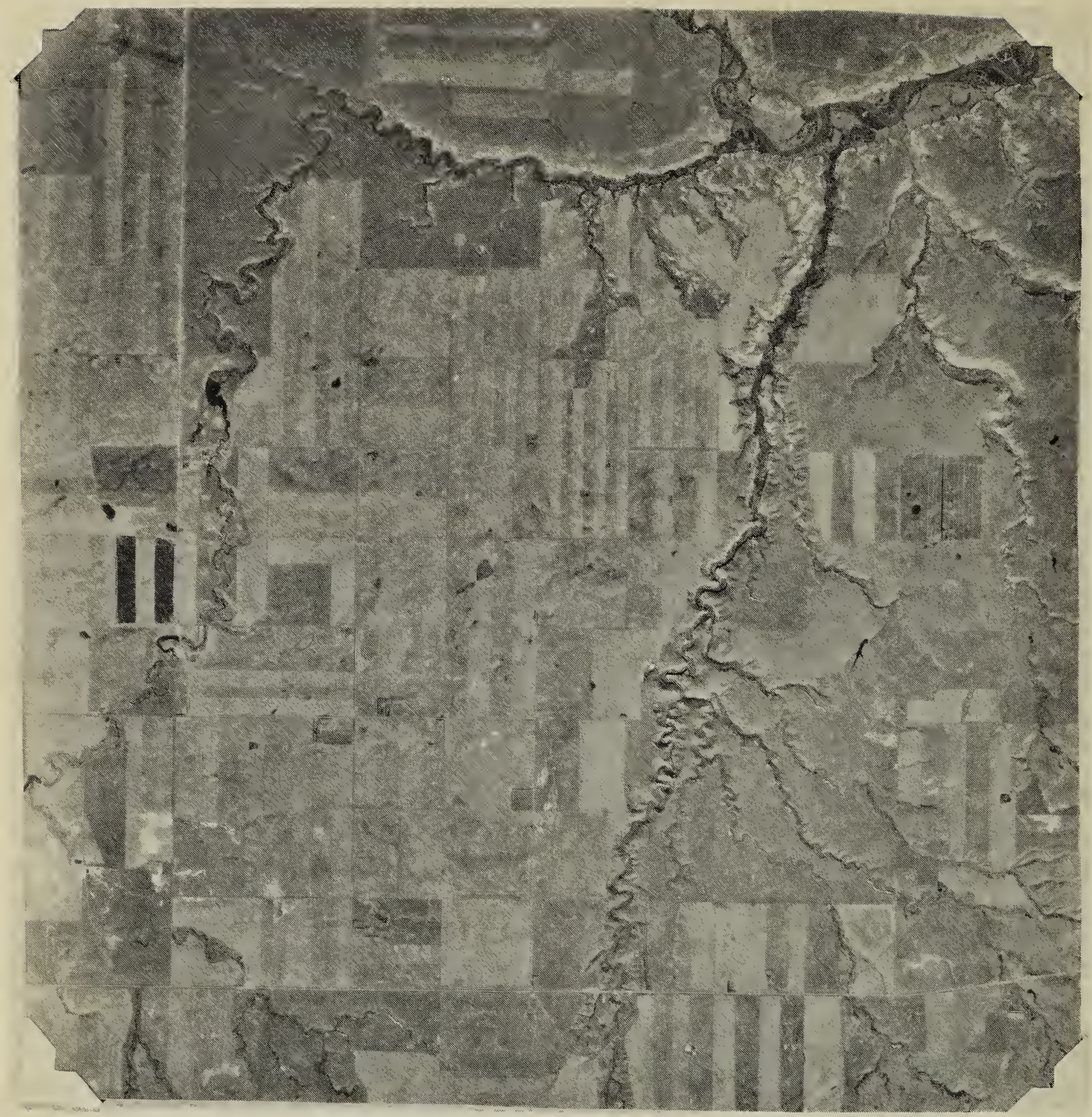

Figure 1. Aerial photo of study area $(1: 60,000)$

bladder pods (Lesquerella spp.), Yellow Prairie Violet (Viola nuttallii) and Prairie Groundsel (Senecio canus).

Shrub communities can be found in the river valley, in the coulee bottoms, and on protected slopes., In this area, they are highly variable and include willows (Salix spp.), Water Birch (Betula occidentalis), Golden Currant. (Ribes aureum), Skunk Bush (Rhus trilobata), Thorny Buffalo-berry (Shepherdia argentea), Chokecherry (Prunus virginiana), Wild Gooseberry (Ribes oxyacanthoides), roses (Rosa spp.), Wolf
Willow (Elaeagnus commutata) and Buckbrush (Symphoricarpos occidentalis). Shrub stands may be of a single species or a mixture of species.

The riverine forest dominated by cottonwoods (Populus sargentii) occurs in scattered stands along the Milk River, and in the major coulees. The main shrubs associated with the riverine forest are willows, Water Birch, Chokecherry, Thorny Buffalo-berry and Red Osier Dogwood (Cornus stolonifera). 


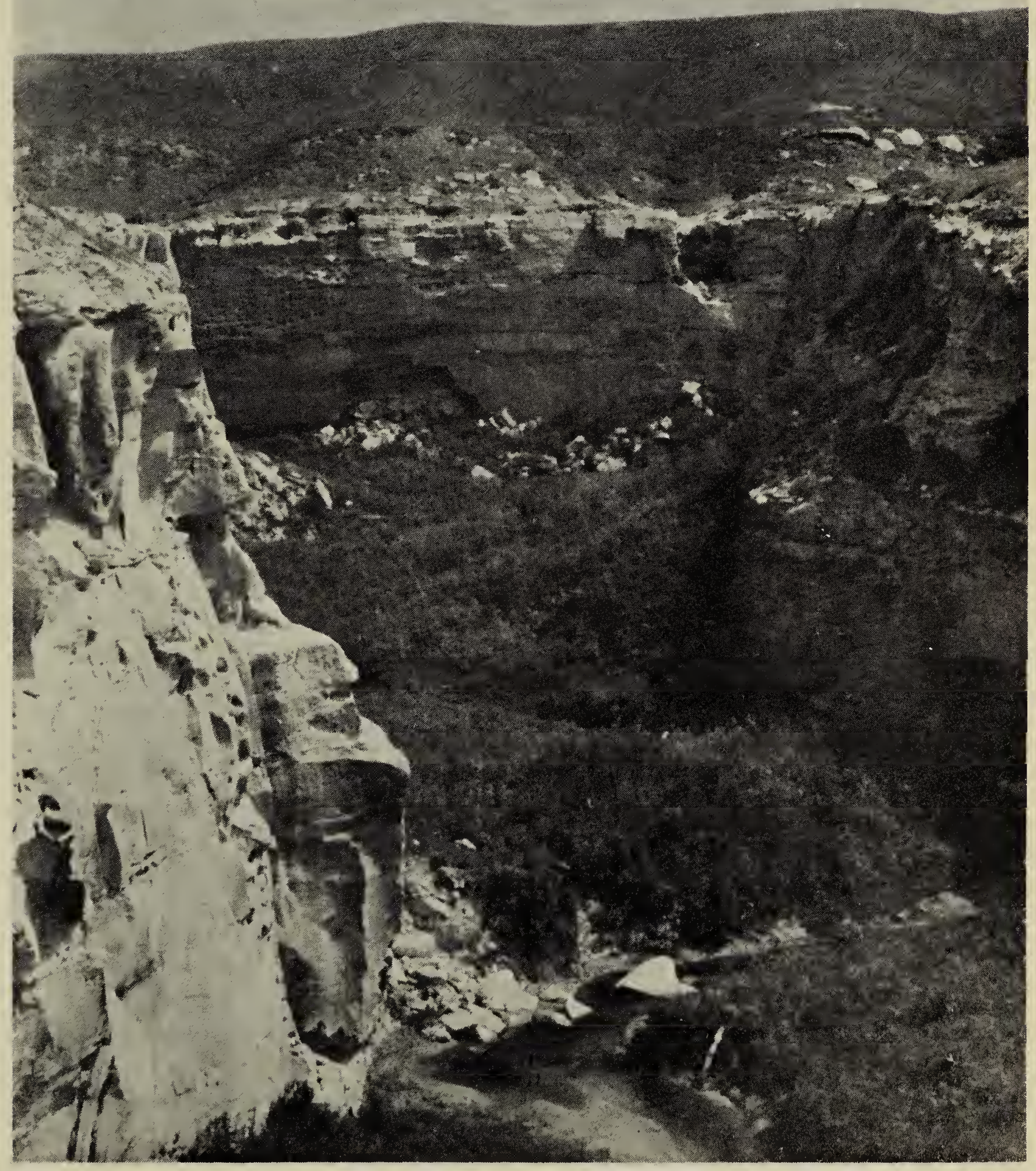




\section{Annotated List}

The following list is the result of field observations and collections made by the authors on 17 different days over a five-year period from 1980 to 1984 . Dates indicating days for which specimen records are available are written in an abbreviated format by day, month, year (e.g. $26 / 6 / 83$ is 26 June 1983). These are given only for the less common species. Included is data collected by Wayne Smith, Felix Sperling and Terry Thormin. These records are acknowledged by their initials following the collection date for those species for which dates are given. For the more common species the flight period is noted by the first and last dates recorded with specimens

Most of the common names in the list are from Pyle. ${ }^{7}$ Scientific names generally follow Howe for genus, and Miller and Brown for species and subspecies. ${ }^{2} 5$

\section{HESPERIIDAE - Skippers}

Silver-spotted Skipper (Epargyreus clarus) Common in shrubbery in coulees and along the river from 10 June to 22 July.

Northern Cloudywing (Thorybes pylades) - Occasional on prairie slopes 10 to 26 June.

Afranius Dusky Wing (Erynnis afranius) Fairly common in grasslands during the last half of May and in late July.

Common Checkered Skipper (Pyrgus communis communis) - Uncommon in dry grasslands: 23/8/76 WS, 7/8/80, 15/7/83.

Garita Skipperling (Oarisma garita) - Fairly common in moist grasslands from 10 June to 9 July.

Uncas Skipper (Hesperia uncas) - Occasional on dry grassy slopes: 22/6/80, 10/7/80.

Assiniboia Skipper (Hesperia comma assiniboia) - Occasional in grasslands: $7 / 8 / 80$.
Yellowpatch Skipper (Polites coras) - Occasional in disturbed grasslands: $15 / 7 / 83$. To date, this is the most southeastern record for Alberta

Tawny-edged Skipper (Polites themistocles) - Scarce in grasslands in the coulees: 26/6/83. Outside of the Cypress Hills, this is the most southeastern record for Alberta.

Long Dash (Polites mystic dacotah) - Uncommon in disturbed grasslands from 22 June to 27 July.

Delaware Skipper (Atrytone logan) - Occasional in low shrubbery in coulees during July. These are the westernmost known records for Alberta.

Roadside Skipper (Amblyscirtes vialis) - Occasional near shrubbery in coulees: 10/6/80 TT.

\section{PAPILIONIDAE - Swallowtails}

Old World Swallowtail (Papilio machaon dodi) - Occasional in grasslands during May and July.

Anise Swallowtail (Papilio zelicaon) - Scarce in grasslands: $27 / 5 / 79$ FS. There is a chance that this record is actually a hybrid with the Old World Swallowtail. It has a round, unconnected anal pupil, but a fair amount of yellow on the claspers (F. Sperling, pers. comm)

Tiger Swallowtail (Papilio glaucus canadensis) - Scarce in tall thickets in coulees: 26/6/83.

Two-tailed Tiger Swallowtail (Papilio multicaudadata) - Fairly common in shrubbery in coulees from 10 June to 22 July.

PIERIDAE - Whites, Sulphurs and Marbles

Western White (Pieris occidentalis) - Fairly common in grasslands and along the 


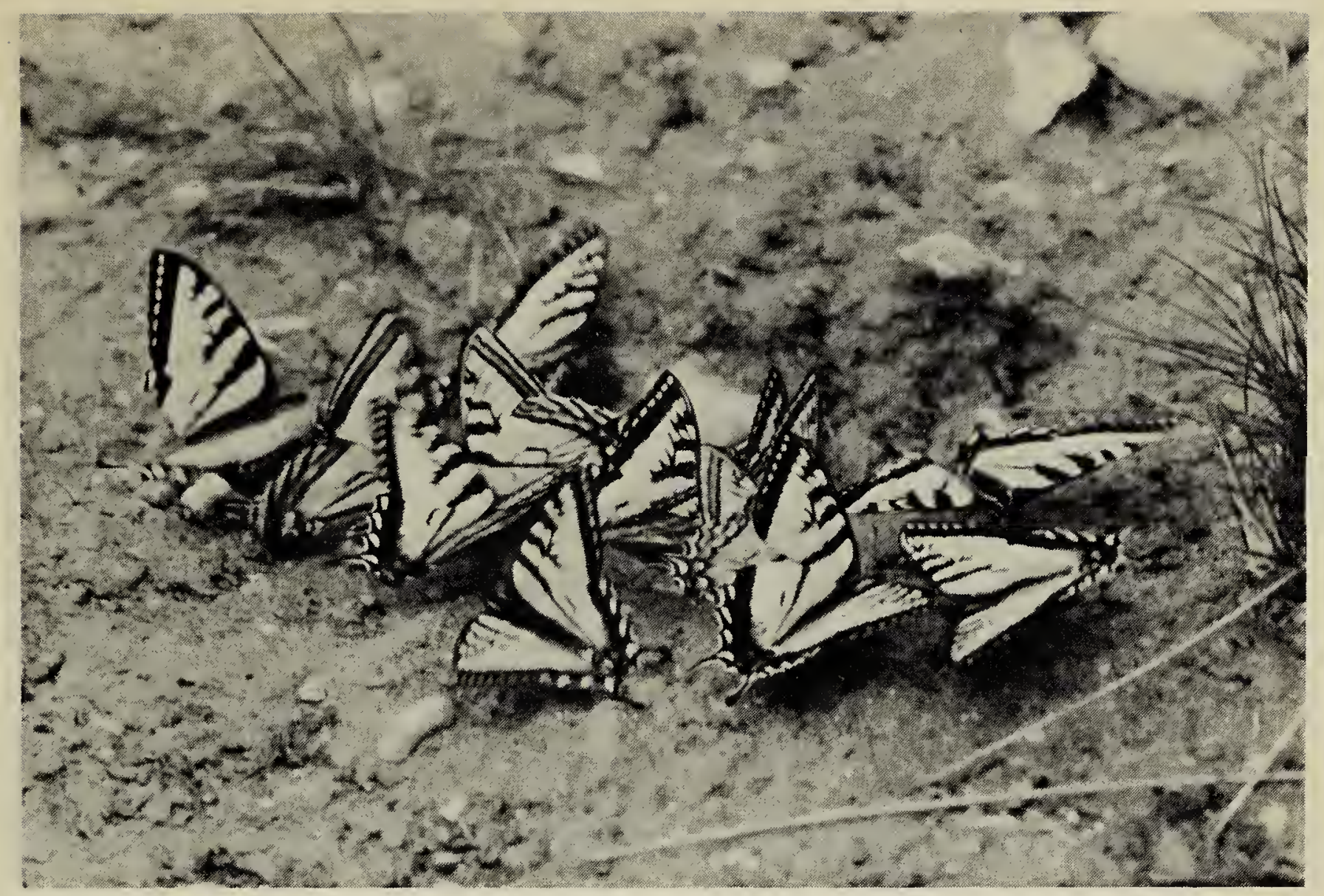

Tiger Swallowtails

Larry Morgotch

edges of coulees from 16 May to 8 August.

Cabbage White (Pieris rapae) - Common in disturbed areas from 28 May to 7 August.

Creamy Marblewing (Euchloe ausonides) Scarce in higher elevation grasslands in June: $10+22 / 6 / 80$.

Olympia Marblewing (Euchloe olympia) Occasional during the latter half of May on bare slopes in the coulees: $28 / 5 / 81$, 16/5/82.

Common Sulphur (Colias philodice eriphyle) - Common in disturbed areas from 6 May to 8 August.

Queen Alexandra's Sulphur (Colias alexandra alexandra) - Uncommon in native grasslands: 10/6/80, 7/8/80, 28/5/81.
LYCAENIDAE - Gossamer-winged Butterflies

Ruddy Copper (Lycaena rubidus) - Scarce; one individual was collected on 11/7/80 in a shady area in Van Cleeve Coulee.

Purplish Copper (Lycaena helloides) - Uncommon along the Milk River and other water courses: 10/6/80, 27/6/83.

Coral Hairstreak (Harkenclenus titus immaculosus) - Uncommon in shrub communities in the coulees during July. These are the southeasternmost records for Alberta, excluding those for the Cypress Hills.

Acadian Hairstreak (Satyrium acadica) Scarce; an individual was collected in shrubbery along Police Creek 23/7/70 WS. 
Striped Hairstreak (Satyrium liparops) Scarce; an individual was recorded 22/7/76 WS in low shrubbery in Police Coulee. This is the southernmost known record for Alberta.

Gray Hairstreak (Strymon melinus) - Occasional in mixed grasslands on the coulee hillsides during May and July: 22/7/76 WS, $16 / 5 / 82$.

Western Tailed Blue (Everes amyntula albrighti) - Occasional in shrub communities in coulees and river valleys: 10/6/80, 26/6/83. Outside of the Cypress Hills, these are some of the most southeastern reports for the province along with those reported for the lower Milk River. ${ }^{4}$

Spring Azure (Celastrina ladon) - Occasional in wooded areas of the coulees and river valley during May: 6/5/76 WS, 16/5/82.

Silvery Blue (Glaucopsyche lygdamus) - Occasional in mixed grasslands: 22/6/80, $16 / 5 / 82$

Melissa Blue (Lycaeides melissa melissa) Common in grasslands from 28 May to 7 August.

Greenish Blue (Plebejus saepiolus amica) Uncommon in disturbed grasslands: 10/6/80, 15/7/83

Pembina Blue (Plebejus icarioides pembina) - Uncommon in mixed grasslands in the southern parts of the coulees closest to the Sweetgrass Hills of Montana from 10 June to 15 July. These records, along with those from the Cypress Hills are the southeasternmost in Alberta.

Shasta Blue (Plebejus shasta minnehaha) Uncommon and local on bare coulee slopes from 10 June to 9 July: 10/6/80, 9/7/80, 26/6/83.

Acmon Blue (Plebejus acmon lutzi) - Uncommon in dry grasslands and on bare coulee slopes: 26/6/83, 21/7/84.
Rustic Arctic Blue (Plebejus franklinii rustica) - Occasional in grasslands: $26 / 6 / 83$. This is one of the most southeastern records for the province.

NYMPHALIDAE - Brush-footed Butterflies

Variegated Fritillary (Euptoieta claudia) Scarce in riverine forest; one 11/7/81.

Great Spangled Fritillary (Speyeria cybele leto) - Fairly common in shrub communities in coulees during July.

Aphrodite (Speyeria aphrodite) - Common in mixed grasslands and shrub communities in the coulees during July and August. The specimens are not like ssp. manitoba from farther north. Generally they are larger and darker indicating transition to ssp. ethne.

Edward's Fritillary (Speyeria edwardsii) - Occasional in shrub communities in coulees from 10 June to 7 August: 10/6/80 TT, 9/7/80, 7/8/80.

Zerene Fritillary (Speyeria zerene) - Scarce in shrub communities in the coulees: $7 / 8 / 80$.

Callippe Fritillary (Speyeria callippe calgariana) - Fairly common in mixed grasslands and shrub communities on coulee hillsides from 22 June to 29 July. Males spend a lot of time patrolling upper coulee edges.

Mormon Fritillary (Speyeria mormonia eurynome) - Scarce in shrub communities in coulees: 23/7/76 WS, 22/6/80.

Silver-bordered Fritillary (Boloria selene) Occasional in low damp areas in the southern parts of the coulee systems during June: $10^{\$ 22 / 6 / 80}$. These are the southeasternmost records for Alberta.

Sagebrush Checkerspot (Chlosyne acastus) - Uncommon on hillsides of the coulees and river valley during July: 21-23/7/76 
WS, 10/7/80. These are the westernmost records along the Milk River drainage, and the southwesternmost records for the province.

Pearl Crescentspot (Phyciodes tharos) Common in grasslands and bordering shrub communities in the coulees from 28 May to 8 August.

Northern Crescentspot (Phyciodes pascoensis) - Scarce in the extreme southern portions of the coulees on the lower slopes of the Sweetgrass Hills. An individual was collected on 22/6/80.

Tawny Crescentspot (Phyciodes batesii) Uncommon in shrub communities in coulees from 10 June to 11 July: 10/6/80, 9-11/7/80. To date these are the most western records of this species along the Milk River drainage.

Anicia Checkerspot (Euphydryas anicia) Scarce; two females were collected by Kondla and Thormin along Police Creek $10 / 6 / 80$. Outside of the Cypress Hills this is the most southeasterly record for the province. These were probably windblown strays from the Sweetgrass Hills populations.

Satyr Anglewing (Polygonia satyrus) - Scarce in poplar woods and shrub communities in coulees and river valley; recorded only during July: 22/7/76 WS, 10/7/80. Outside of the Cypress Hills, these are the southeasternmost records for Alberta.

Gray Comma (Polygonia progne) - Only one record of an individual 22/7/76 WS in a shrub community in Police Coulee. This is one of the most southeasterly records for the province outside of the Cypress Hills.

Compton Tortoiseshell (Nymphalis vaualbum) - Uncommon in shrub communities in coulees: 6/5/76 WS. These are the southeasternmost reports for the province.

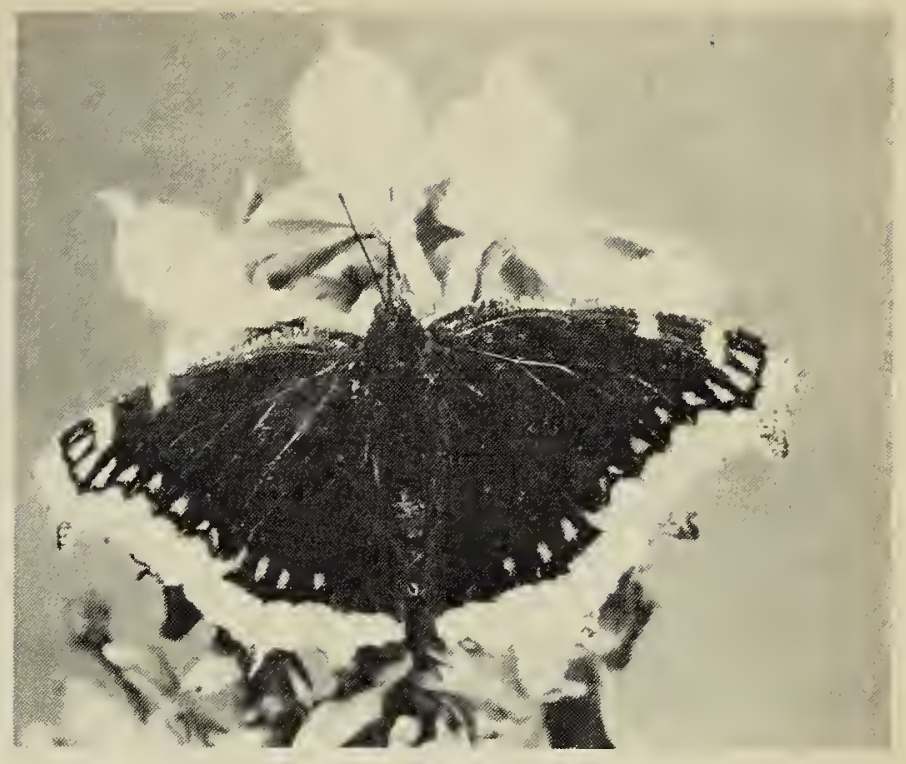

Mourning Cloak

R.E. Gehlert

Mourning Cloak (Nymphalis antiopa) - Fairly common in May, occasional during rest of the flight period in poplar woods and shrub communities in the coulees and river valley: 6/5/76 WS, 6/7/76 WS, 20/7/84.

Milbert's Tortoiseshell (Nymphalis milberti) - Uncommon in poplar woods and shrub communities in the coulees and river valley: 10/6/80, 27/6/83, 15/7/83.

Painted Lady (Vanessa cardui) - Common in 1983 commencing in late June in all habitats: $26-27 / 6 / 83,15 / 7 / 83$.

Red Admiral (Vanessa atalanta) - Scarce in disturbed areas in coulees: 28/5/81.

White Admiral (Limenitis arthemis rubrofasciata) - Occasional in poplar woods in river valley and in shrubbery in coulees: 22/7/76 WS, 10/6/80 TT. These are the most southeastern records for Alberta outside of the Cypress Hills.

Weidemeyer's X White Admiral (Limenitis weidemeyerii $\times$ L. arthemis) - Uncommon in shrub communities in Police Coulee from 10 June to 23 July. It is interesting to note that to date no Weidemeyer's have been found in the study area although it has been reported for the lower Milk River. ${ }^{8}$ Kondla : has 
also found it in the Sweetgrass Hills. Examinations by the authors of the Weidemeyer's specimens from Writingon-Stone reported by Smith and Bird in 1977 has resulted in changing their identification to hybrids.

Viceroy (Limenitis archippus) - Common in poplar woods and shrub communities along the Milk River and in the coulees during July.

SATYRIDAE - Meadow Browns

Prairie Ringlet (Coenonympha inornata benjamini) - Fairly common in grasslands from 28 May to 26 June.
Large Wood Nymph (Cercyonis pegala ino) Common in grasslands from 11 July to 29 August.

Small Wood Nymph (Cercyonis oetus) Common in grasslands from 11 July to 29 August.

Riding's Satyr (Neominois ridingsii) - Occasional in dry grasslands: 10-11/7/80.

Uhler's Arctic (Oeneis uhleri varuna) - Occasional in dry grasslands during late May and early June: 28/5/81.

Alberta Arctic (Oeneis alberta) - Occasional in dry grasslands in the latter half of May: $16 / 5 / 82$.

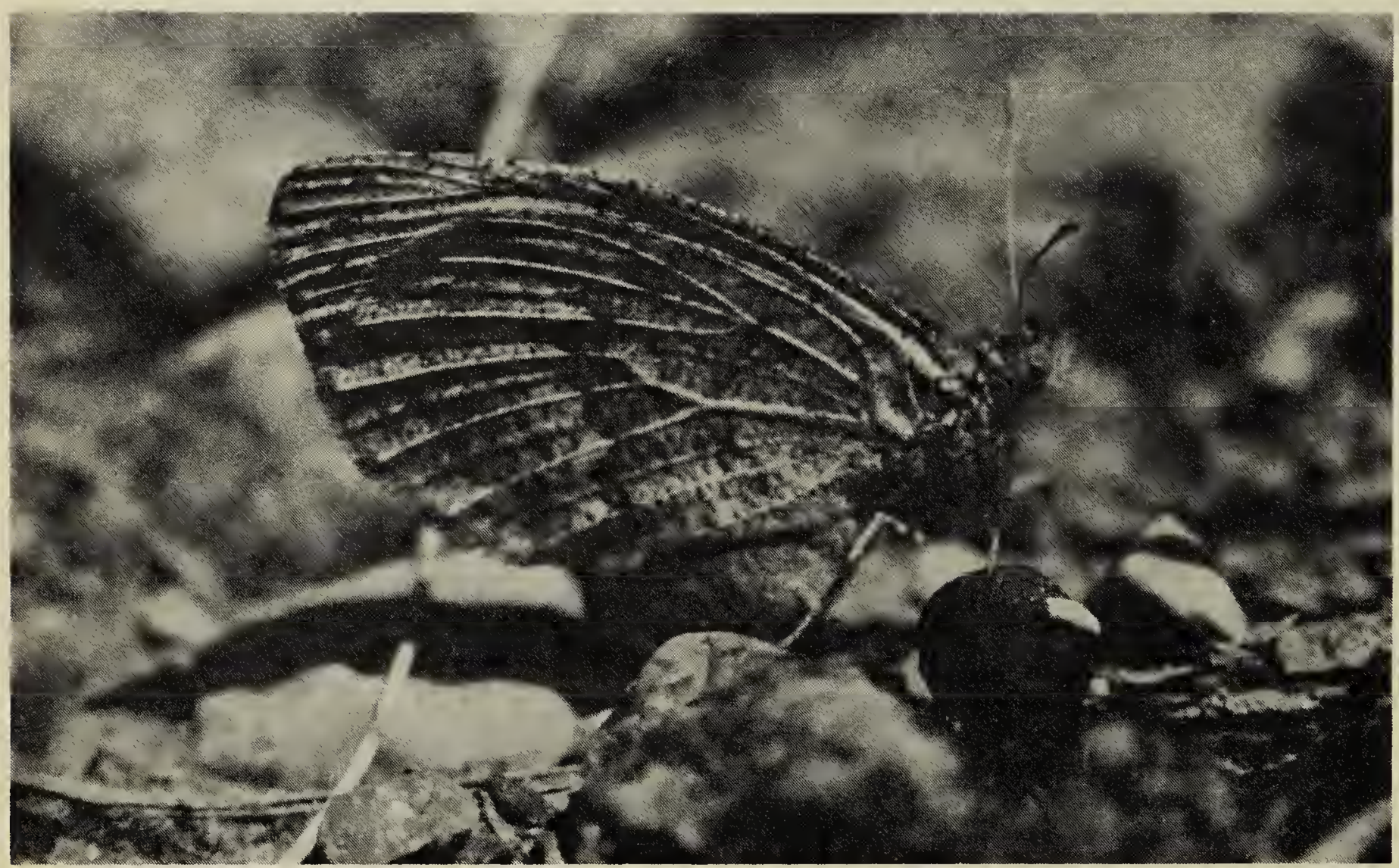

Riding's Satyr

Gary W. Seib

\section{Discussion}

Sixty-six species, representing six of the seven families of butterflies found in Alberta were recorded in the study area. Table 1 compares the Rhopaloceran fauna of the study area to that of Alberta. There is a slightly lower representation of Pierids and Satyrids in the study area as compared to the provincial fauna. This is the result of a lack of any coniferous woods habitat and the fact that many species in these families have more northern and western distributions. In the Police Coulee fauna $56 \%$ of taxa have a widespread Alberta distribution, $17 \%$ are from prairie/parkland, $14 \%$ from prairie only, $12 \%$ with a prairie/cordilleran distribution and $1 \%$ are found only in cor- 
Table 1. COMPARISON OF POLICE COULEE STUDY AREA AND PROVINCIAL RHOPALOCERAN FAUNA

Family

Police Coulee

Province

\# of Species

$\%$ of Fauna

\# of Species

$\%$ of Fauna

Hesperiidae

Palpilionidae

Pieridae

Lycaenidae

Nymphalidae

Danaidae

Satyridae

Totals

$\begin{array}{r}12 \\ 4 \\ 6 \\ 15 \\ 23 \\ 0 \\ 6 \\ \hline 66\end{array}$

$\begin{array}{r}18 \\ 6 \\ 9 \\ 23 \\ 35 \\ 0 \\ 9 \\ \hline\end{array}$

dilleran habitats. The Anicia Checkerspot is the cordilleran species recorded in this area, and occurs only as windblown strays from the Sweetgrass Hills.

Of the 66 species recorded for the study area 19 were recorded during May, 34 during June, 43 during July and 13 during August. The greatest diversity of species occurs in mid-July. It is interesting to note that this mid-July peak in this grassland ecoregion coincides with that found in the mainly mountain forest study areas of Banff National Park and the Indian Grave area. ${ }^{16}$ The best places to observe butterflies in the study area are the coulee edges, the shrub and treed areas, and along the creeks. recorded for the Police Coulee area is the result of the interspersion of a number of different habitats and the proximity of the Sweetgrass Hills. Another area that has been extensively studied in southern Alberta is the Milk River - Lost River area located about 50 mi. east of Police Coulee. 34810 Both areas have similar habitats, except the lower Milk River - Lost River area lacks the coulees connecting directly to the Sweetgrass Hills and the higher elevation grasslands of the Mixed Grass Ecoregion. Table 2 compares the butterfly fauna of the two areas on a family level.

The Police Coulee area is a meeting area of western and eastern species. A number

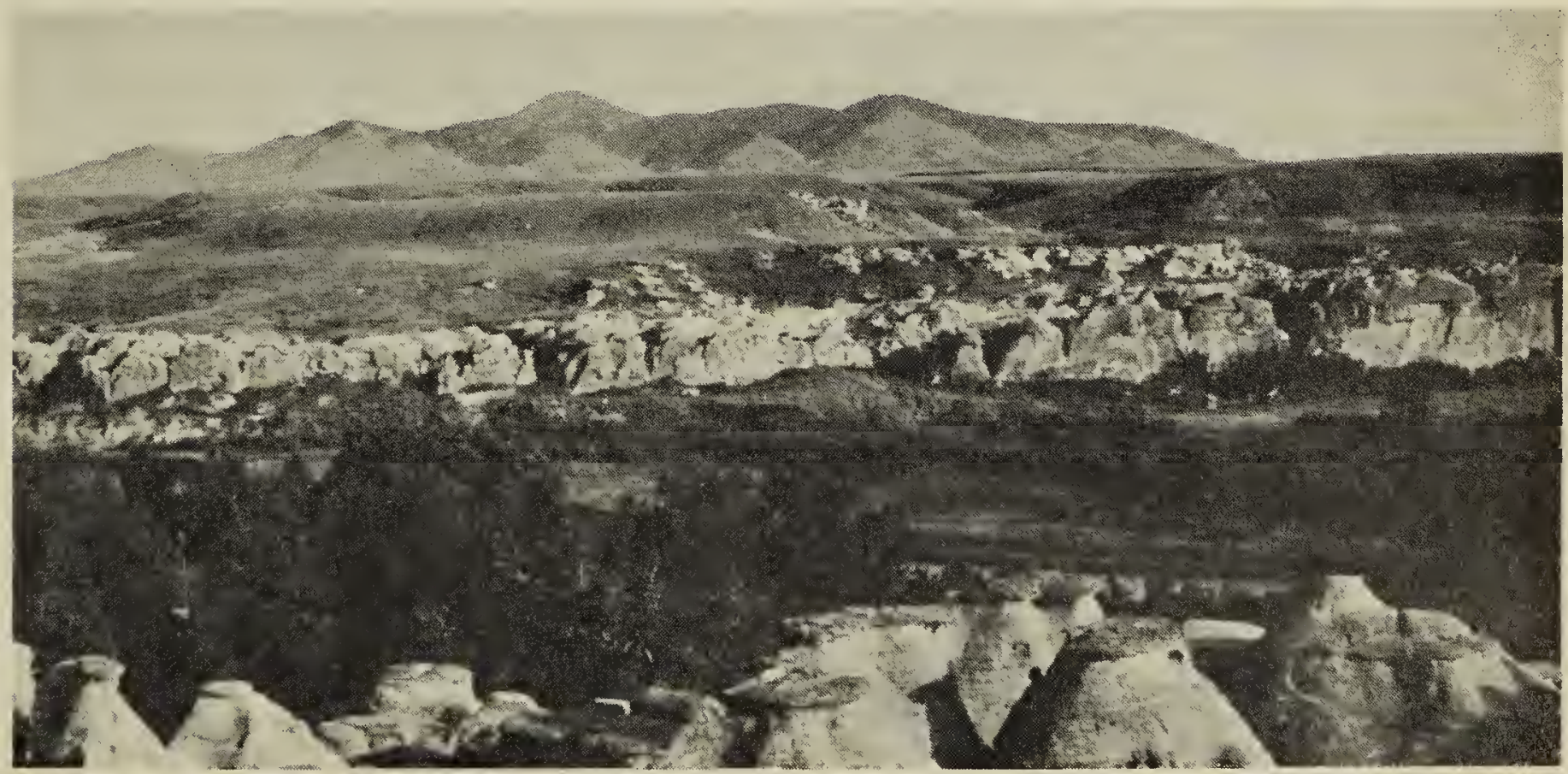

View of study area looking from north boundary to the south H.W. Pinel 


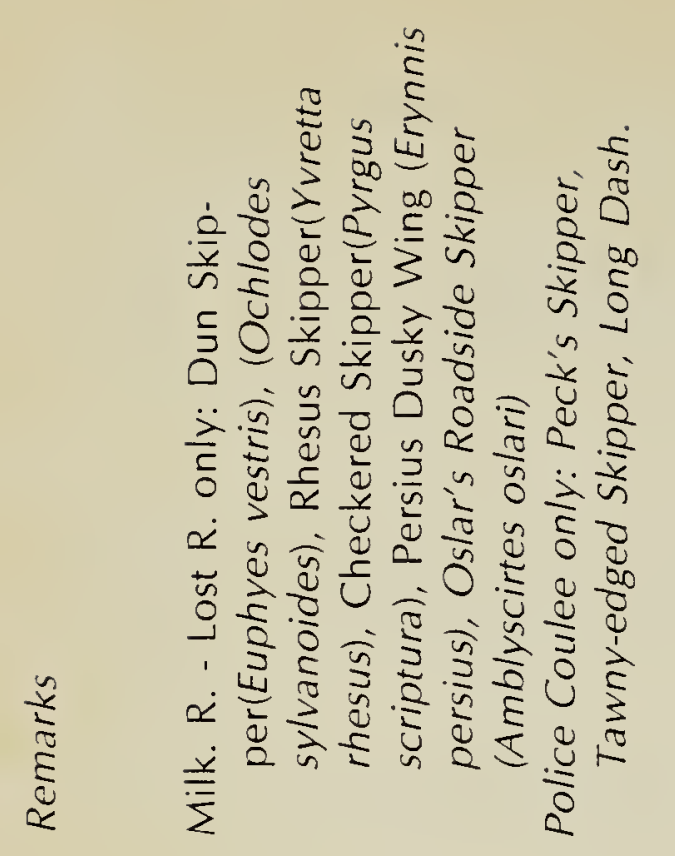

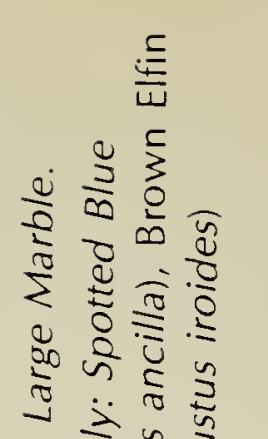

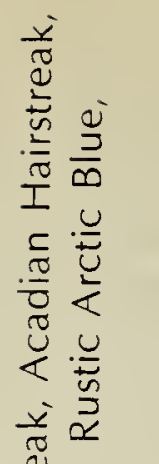

$\sum_{\substack{i \\ \infty}}^{\infty}$

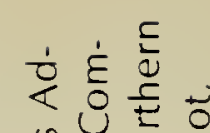

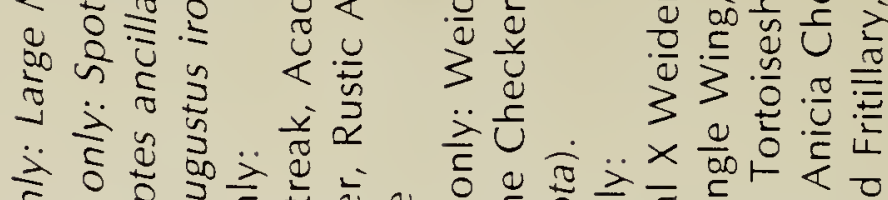

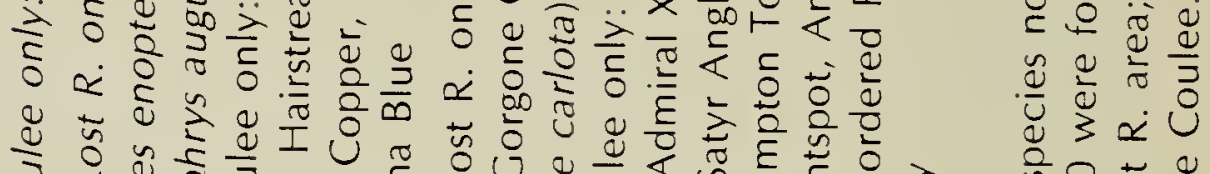

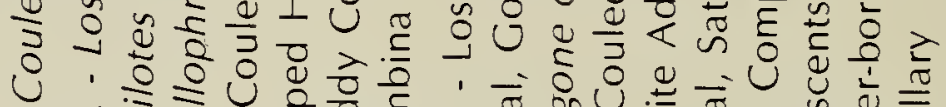

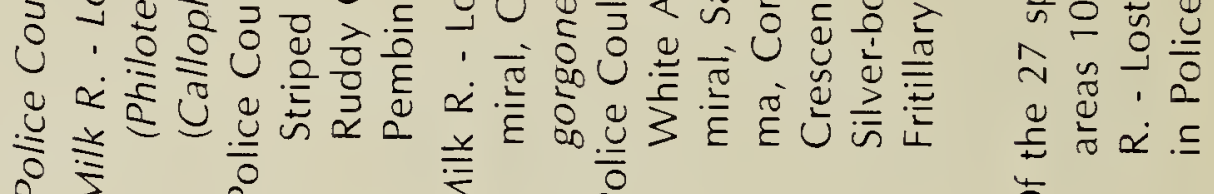
2 之 0 要

$$
o-n
$$$$
\sin ?
$$

$+6 \approx$

$+6 \leqslant$

$\sin \approx$

$\stackrel{n}{\sim}$

og

0

$\stackrel{\sim}{\sim}$

68

ข

6 in

0
$z$
0
$\frac{N}{\alpha}$
$\frac{1}{\alpha}$
0
0

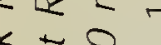

$\sum 0$

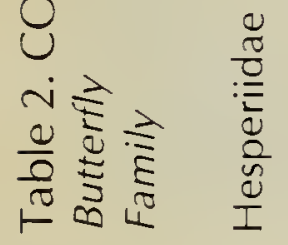

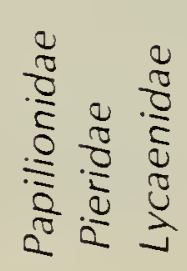

$\frac{\frac{\pi}{0}}{\frac{\pi}{0}}$

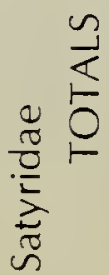


of butterfly species are at the limits of their known range in Alberta. The Delaware Skipper, Sagebrush Checkerspot and Tawny Crescentspot are at the western edge of their range along the Milk River drainage. Examples of species at the southeastern edge of their known range in Alberta. include Yellowpatch Skipper, Tawny-edged Skipper, Pembina Blue, Satyr Anglewing, Gray Comma, Compton Tortoiseshell, Anicia Checkerspot and Silver-bordered Fritillary.

Similar habitat and larval food plants exist in the Police Coulee area for those 10 species already recorded for the Milk River - Lost River area, but not at Police Coulee (Table 2). Of these 10 species the authors feel that the chances of recording Rhesus Skipper (Yvretta rhesus) and Small Checkered Skipper (Pyrgus scriptura) are much less due to their distribution; these are probably strays to Alberta from the United States. Additional species likely to be found in the area include Nevada Skipper (Hesperia nevada), Great Copper ( $L y$ caena xanthoides), Meadow Fritillary (Boloria bellona), Edith's Checkerspot (Euphydryas editha), Green Comma (Polygonia faunus rusticus) and Common Alpine (Erebia epipsodea). Because Police Coulee is at the southern edge of the province next to the Sweetgrass Hills new species for Alberta recorded as migrants, windblown strays or range extensions are more likely to be found here than in most other parts of the province.

\section{Acknowledgements}

Thanks are extended to Wayne Smith, Felix Sperling and Terry Thormin for their observations. Linda Pinel typed the manuscript.

1 BIRD, C.D. 1975 A calendar of the skippers and butterflies of Banff National Park. Alberta Naturalist 5:71-75.

2 HOWE, W.H. 1975 The butterflies of North America. Doubleday and Company Inc., N.Y. $633 \mathrm{pp}$.
${ }^{3}$ KONDLA, N.G. 1983 Additional records of skippers and butterflies from Dinosaur Provincial Park. Alberta Naturalist 13(4):152-157.

${ }^{4}$ KONDLA, N.G., T.W. THORMIN and T. PIKE 1981 Oslar's Roadside Skipper in Alberta. Alberta Naturalist 11(1):15-16.

5 MILLER, L.O. and F.M. BROWN 1981 A catalogue/checklist of the butterflies of America north of Mexico. The Lepidopterists Society, Memoir No. 2. 280 pp.

${ }^{6}$ PINEL, H.W. 1983 Skippers and butterflies of the Indian Grave Campground area, Alberta. Blue Jay $42(2): 71-77$.

7 PYLE, R.M. 1981 The Audubon Society field guide to North American butterflies. Chanticleer Press. N.Y. 916 pp.

${ }^{8}$ SMITH, W.W. and C.D. BIRD 1977 Some butterflies and skippers from the Milk River - Lost River area of southeastern Alberta. Blue Jay 35(1):15-18.

9 STRONG, W.L. and K.R. LEGGAT 1981 Ecoregions of Alberta. Alberta Energy and Natural Resources, Tech. Rept. No. T/4. 64 pp.

10 THORMIN, T.W., N.G. KONDLA and C.D. BIRD 1980 Further records of skippers and butterflies from the Milk River - Lost River area of southeastern Alberta. Blue Jay 38(1):5-10.

EDITOR'S NOTE: Rhesus Skipper and Small Checkered Skipper both occur in Saskatchewan as fresh specimens that are apparently locally emerged. -- Ron Hooper.

CORRECTION.. In the article Skippers and Butterflies of Crimson Lake Provincial Park, Alberta by Harold W. Pinel [Blue Jay 43(3):155-159] there was an omission of several lines from the text of page 158. The article should read as follows:

Frigga Fritillary (Boloria frigga saga) - Occasional in damp grassy areas bordering tamarack bogs; 10-11/6/83, 14/6/84.

Freija Fritillary (Boloria freija freija) - Common in mixed woods and pine woods; flight period recorded form 16 May to 16 June; 16/5/78, 31/5/79, 10-11/6/83, $18+20 / 5 / 84,15-16 / 6 / 84$. 